\title{
Structural biology and evolution in the monotypic Amazonian palm Wendlandiella (Arecoideae: Chamaedoreeae)
}

\author{
Fred W. Stauffer, Joan Eychenne, Nesly Ortega \& Henrik Balslev
}

\begin{abstract}
STAUFFER, F.W., J. EYCHENNE, N. ORTEGA \& H. BALSLEV (2019). Structural biology and evolution in the monotypic Amazonian palm Wendlandiella (Arecoideae: Chamaedoreeae) Candollea 74: 15-30. In English, English abstract. DOI: http://dx.doi.org/10.15553/c2019v741a3

The structural biology is here, for the first time, described in the Amazonian palm genus Wendlandiella Dammer, a poorly known and monotypic member of the early divergent tribe Chamaedoreeae Drude (Arecoideae). Wendlandiella gracilis Dammer includes three varieties: var. gracilis, var. polyclada (Burret) A.J. Hend., and var. simplicifrons (Burret) A.J. Hend. In contrast to the overwhelmingly monoecious condition in this subfamily, Wendlandiella together with the species-rich genus Chamaedorea Willd., presents a dioecious reproductive syndrome. The terrestrial root system, the leaves and the stems of Wendlandiella display a relatively simple architecture and vegetative multiplication observed in wild populations may be regarded as an important mechanism of reproduction. Flowers in Wendlandiella are arranged in a complex floral cluster known as acervulus, clearly deviating from the floral triad characterizing most other members of the subfamily. Our study describes the structure of the acervulus in inflorescences of both sexes. The lack of a nectariferous epithelium in the gynoecium and the pistillode suggests that Wendlandiella is wind pollinated, which is a rare pollination mechanism in palms. Wendlandiella is proposed as an interesting model to test the different evolutionary pathways to dioecy in palms.
\end{abstract}

\section{Keywords}

ARECACEAE - PALMAE - Wendlandiella - Morphology - Anatomy - Dioecy - Neotropics

Addresses of the authors:

FWS: Conservatoire et Jardin botaniques de la Ville de Genève et Laboratoire de systématique végétale et biodiversité de l'Université de Genève, C.P. 71, 1292 Chambésy, Switzerland. E-mail: fred.stauffer@ville-ge.ch

JE: AgroParisTech - Montpellier Center, Campus d'Agropolis 648 rue Jean-François Breton BP 44494 34093, Montpellier cedex 5, France.

NO: University of San Marcos, Lima, Peru.

HB: Department of Bioscience, Section of Ecoinformatics and Biodiversity, Aarhus University, Ny Munkegade 114 - 116, 8000 Aarhus C, Denmark.

Submitted on September 14, 2018. Accepted on January 26, 2019.

First published online on March 28, 2019. 


\section{Introduction}

Wendlandiella Dammer is a monospecific genus ( $W$. gracilis Dammer) including three varieties (var. gracilis, var. polyclada (Burret) A.J. Hend., and var. simplicifrons (Burret) A.J. Hend.). It belongs to the tribe Chamaedoreeae Drude (Arecoideae) and is a small understory rainforest palm in the western Amazon basin. It belongs to Arecoideae which is the largest and most diverse palm subfamily (Dransfield et al., 2008), characterized by a combination of reduplicate and pinnate leaves, highly differentiated primary inflorescence bracts, and having the flowers arranged in triads or a derivative thereof (Dransfield et al., 2008; BaKer et al., 2011). In particular the last character has been recognized as an important synapomorphy for the subfamily (14 in total), and the only exception is Chamaedoreeae, in which some members have a complex floral cluster known as the acervulus (Uhl \& Moore, 1978; Dransfield et al., 2008; Ortega-Chávez \& Stauffer, 2011). Chamaedoreeae also deviate from other Arecoideae in several members being dioecious in contrast to the overwhelmingly monoecious condition in the subfamily (NADOT et al., 2016).

As currently circumscribed, the tribe Chamaedoreeae includes 115 species in four neotropical genera (Chamaedorea Willd., Gaussia H. Wendl., Synechanthus H. Wendl., Wendlandiella Dammer) and a geographically disjunct Mascarene endemic, Hyophorbe Gaertn. (Dransfield et al., 2008). The ancestor of Chamaedoreeae originated on the Mascarene Islands (present day locality of Hyophorbe), then migrated to South America (in which Wendlandiella is found today) and spread north from South America to Central America and the Caribbean (present day distribution of Synechanthus, Gaussia, and Chamaedorea) (Moore, 1975; Henderson, 1995; Cuenca et al., 2009; Cano, 2018). Hyophorbe is sister to the remaining genera of Chamaedoreeae, and Wendlandiella is an early divergent lineage clearly separated from Chamaedorea (Thomas et al., 2006; Cuenca et al., 2008). Based on the arrangement of staminate flowers and male and female floral anatomy Wendlandiella most closely resembles Synechanthus (Henderson, 1995; Ortega, 2010).

Wendlandiella is mainly distributed in the Peruvian Amazon but also occurs in neighboring Bolivia, western
Brazil (Acre), and southern Ecuador, at altitudes ranging from 100-700 m. A recent revision of the genus (EYchenNe et al., 2018) supports former preliminary circumscriptions (i.e. Henderson, 1995; Henderson et al., 1995) and recognizes one polymorphic species $W$. gracilis, with three varieties: var. gracilis, var. polyclada, var. simplicifrons, separated on a restricted set of morphological characters, as well as their non-overlapping geographical distribution. Wendlandiella and Chamaedorea share resemblances in habitat, growth habit, vegetative morphology, and a dioecious reproductive system, but several characters clearly differentiate them (UHL \& Dransfield, 1987; Hodel, 1992; Cuenca et al., 2009). Wendlandiella consistently has only one peduncular bract, flowers with gibbous, basally connate sepals, and fruits with a membranous endocarp, whereas Chamaedorea has multiple peduncular bracts (e.g. up to ten in female inflorescences of $C$. elegans Mart.), flowers with sepals connate to various degrees, and fruits with a hard endocarp.

Although taxonomically rich and well represented in the understory of Neotropical rainforests, studies of reproductive biology in Chamaedoreeae are restricted to one species of Wendlandiella and three species of Chamaedorea (BARFOD et al., 2011). There is a conspicuous nectary in the pistillode of Gaussia (CAstaño et al., 2014), and there are nectar ducts in male and female flowers of Hyophorbe lagenicaulis (L.H. Bailey) H.E. Moor (Ortega-Chávez \& Stauffer, 2011), suggesting insect pollination in Chamaedoreeae. On the other hand Wendlandiella has no fragrance on either the male or the female inflorescence, and insect visitation is absent, suggesting that it is wind pollinated (Listabarth, 1992). Wind pollination is rare among palms and makes up only $7 \%$ of the documented cases in the family (Henderson, 1986; BARFoD et al., 2011).

In spite of the interesting phylogenetic position of Chamaedoreeae, which is often recovered together with Iriarteeae as the earliest diverging arecoid lineage (BAKER et al., 2011; Comer et al., 2015; CANo, 2018), we know little about their morphology and anatomy. The fact that some members display reproductive structures (i.e., acervulate floral units) and sexual expression (dioecy), which are remarkably divergent compared to most tribes in the Arecoideae, makes it particularly

Table 1 - Details of fresh material sampled in varieties of Wendlandiella gracilis.

\begin{tabular}{llll}
\hline Variety & Origin of the plant & Collection data & Material \\
\hline gracilis & Cult. at University of Halle Wittemberg (Germany) [Originally from Peru] & II.2010, N. Tkach \& M. Röser s.n. (G spirit coll.) & $\hat{0}$ \\
polyclada & Iquitos (Peru) & VII.2009, F. Stauffer \& N. Ortega s.n. (G spirit coll.) $\quad \hat{\sigma}$ \\
polyclada & Iquitos (Peru) & II.2010, V. Vargas s.n. (G spirit coll.) \\
polyclada & Cult. at IRD-Montpellier [Originally from plants cultivated at FTG] & III.2017, J. Eychenne s.n. (G spirit coll.) \\
polyclada & $\begin{array}{l}\text { Cult. at CJBG [Acc. no 20161801J0] } \\
\text { [Originally from plants cultivated at IRD-Montpellier] }\end{array}$ & $\begin{array}{l}\text { VII.2017, J. Eychenne \& F. Stauffer s.n. } \\
\text { (G spirit coll.) }\end{array}$ \\
\hline
\end{tabular}


A

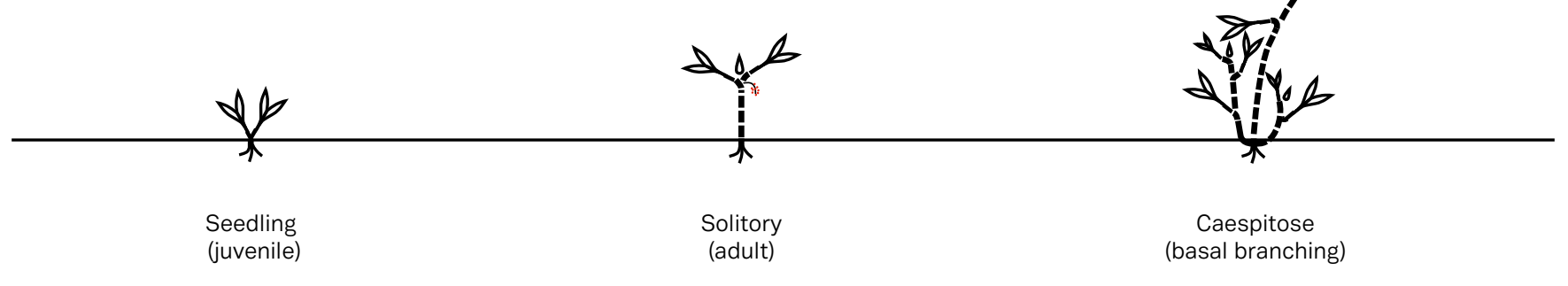

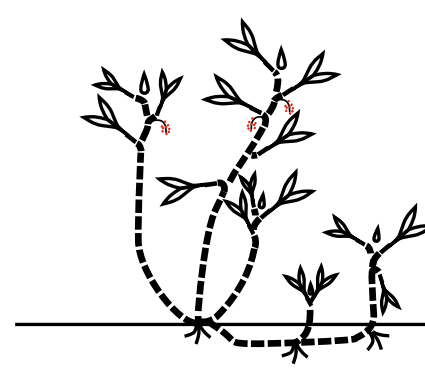

Clusters (stolon)

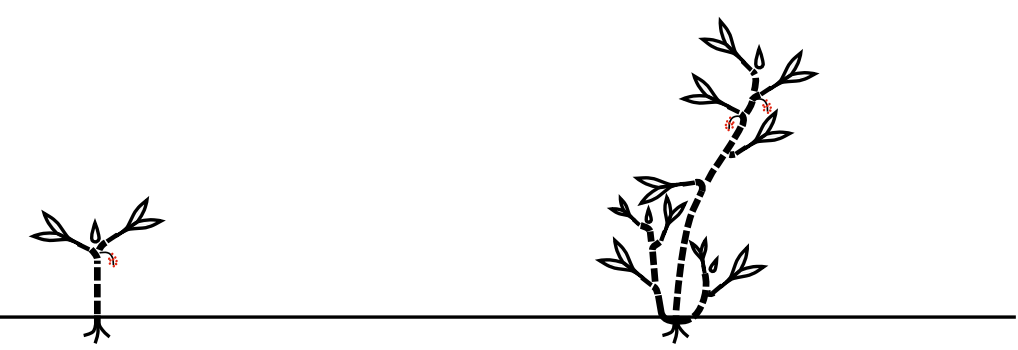

(basal branching)
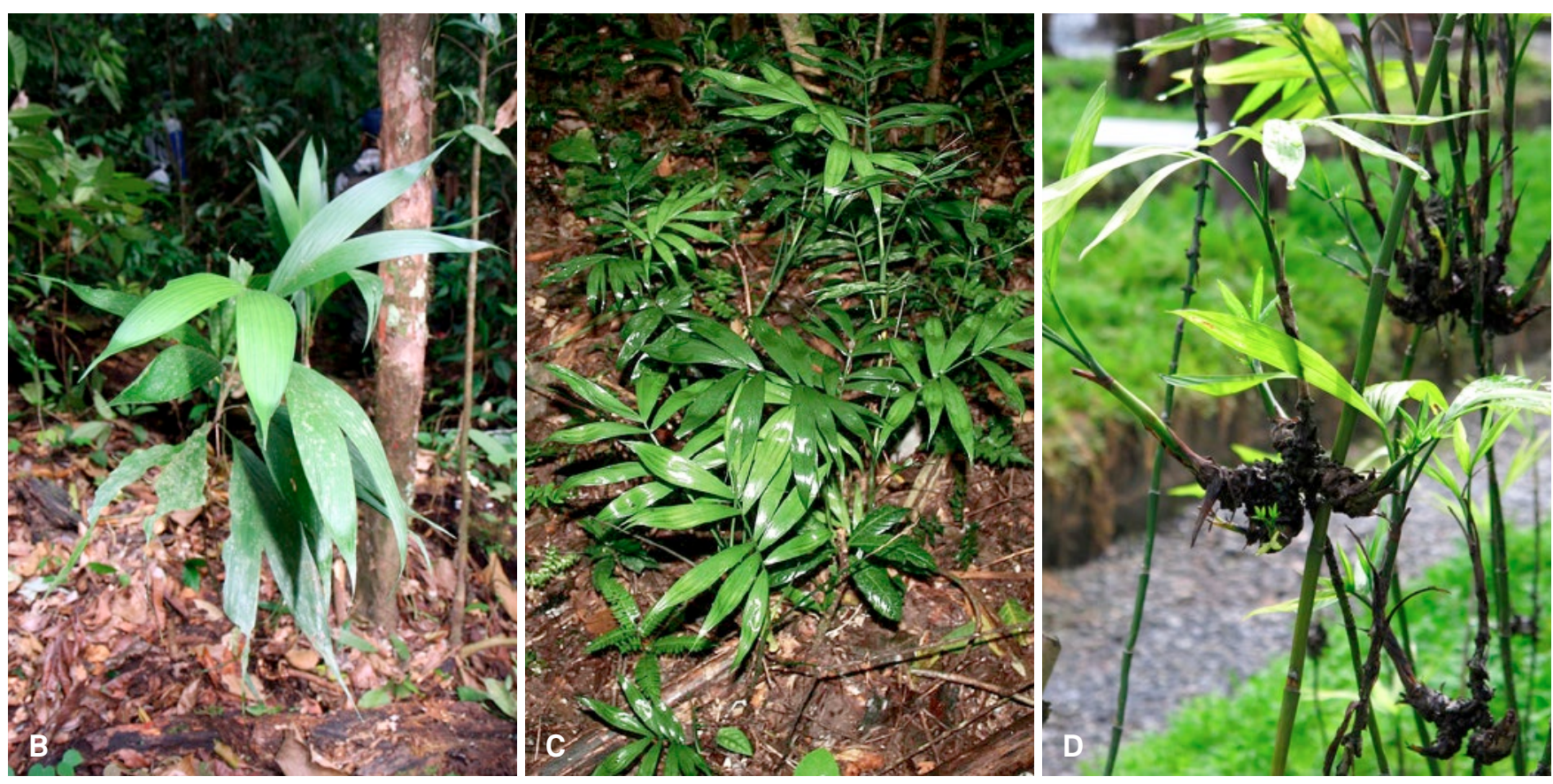

Fig. 1. - Growth habit diversity in Wendlandiella gracilis.

A. Schematic representation of the development of stems and major types of growth habit; B. Solitary growth habit (var. simplicifrons);

C. Clustered growth habits (var. gracilis); D. Production of new plantlets from aerial stems (var. simplicifrons).

[B: Balslev et al., 7677, AAU; C: Balslev et al., 7865, AAU] [Photos: B, C: H. Balslev; D: S. Zona, taken in Nongnooch Tropical Garden,

Pattaya, Thailand] 
important to characterize the morphology and anatomy of the Chamaedoreeae. This is particularly true for the monotypic Wendlandiella, which remains a rather enigmatic palm genus endemic to the western Amazon basin. Here we provide a detailed description of the structural biology of this genus and discuss it in the context of reproduction and evolution of Chamaedoreeae and palms in general.

\section{Material and Methods}

\section{Plant material}

Fresh material of roots, stems and leaves of Wendlandiella gracilis var. gracilis and $W$. gracilis var. polyclada were sampled for morphological and anatomical studies. Most of the material originates from wild populations in Peru or was cultivated in several botanical gardens in Europe (Table 1). The macromorphological analysis is also based on the study of specimens of Wendlandiella deposited at the following herbaria: AAU, B, BH, C, CEN, F, FTG, G, GH, HAL, INPA, K, LPB, MO, NY, US, USM, and WU. A detailed list of studied herbarium specimens can be found in Eychenne et al. (2018).

\section{Morphological and anatomical studies}

For the anatomical study, roots, leaves, flowers at late bud stage and sections of rachillae containing acervuli were sampled, dehydrated and embedded in Kulzer's Technovit 7100 (2-hydroxyethyl metacrylate [HEMA]) (Igersheim \& Сісноскі, 1996). The material was cross- and longitudinallysectioned at 7-10 microns using a rotary microtome (Leitz 1512), stained with ruthenium red and toluidine blue, and embedded in Histomount. Observations and photographs were made at the Laboratory of Micro-Morphology of the Conservatoire et Jardin botaniques de Genève [CJBG] and the Unite d'histologie et de cytologie végétales of the University of Geneva; permanent slides are deposited at the Laboratory of Micro-Morphology at the CJBG. Images of the anatomical sections were captured with a light microscope (Nikon Elipse80i), using the image processing software for the microscope NIS-Elements (Nikon), then stitched with Image J (Preibisch et al., 2009) and finally edited in Adobe Photoshop Elements (6.0 version) and Adobe Illustrator (CS4 version). For Scanning Electron Microscopy (SEM), the dissected specimens were dehydrated in an ethanol series and acetone, and then critical point dried, and sputter-coated with gold. Micrographs were made with a Zeiss DSM 940A scanning electron microscope (Orion 6.60 Imaging System) at the Muséum d'histoire naturelle de Genève [MHN]. Images of living plants were recovered from the rich database of the AAU herbarium (AAU, 2019).

\section{Results}

\section{Stem and growth habit}

Wendlandiella are dwarf palms, occasionally solitary or more often many-stemmed (Fig. 1A-D). Clusters of 2-8 individuals grow in dense clumps separated by empty spaces. The stem height varies from $0.2-1.5 \mathrm{~m}$, even though the collections Killip and Smith 26515 and 27715 (NY) noted 6-8 feet height (1.8-2.4 $\mathrm{m}$ height). The diameter of the stem ranges from $0.2-1 \mathrm{~cm}$, and they are erect or slightly leaning, procumbent, or rarely climbing. More than being a true climber, Wendlandiella seems to lean on surrounding vegetation and does not appear to modify stem properties with age, so it can be considered as a partly self-supporting species. Vegetative reproduction by basal branching and stem leaning seems to be a frequent process in these palms (Fig. 1A). The internode length ranges from 2-6 $\mathrm{cm}$; they are glabrous and green. The stem is mostly round in cross section, although some are slightly flattened. Each stem is conspicuously ringed with non-prominent leaf scars. New roots emerge directly from the stem and appear below the ring nodes while new plantlets arise from them. Wendlandiella gracilis var. simplicifrons and var. polyclada display this trait (A. Lindstrom, pers. comm.), which represents an efficient horticultural method for vegetative reproduction (Fig. 1D).

\section{Root anatomy}

The primary roots of Wendlandiella are $0.1-4 \mathrm{~mm}$ in diameter with a brown mature epidermis. The columella root cap (studied in W. gracilis var. polyclada) is composed of up to 20 cell layers (Fig. 2A). The quiescent center of the meristematic region has rectangular cells with large nuclei and anticlinal and periclinal divisions. The lateral root cap is $4-5$ cell-layers thick and has a complex exfoliation pattern. Wendlandiella has abundant root hairs. The epidermis of Wendlandiella is one cell-layer thick and is made up of square cells with wide nuclei. A rhizodermis and a 1-layered exodermis are well differentiated (Fig. 2E).

The cortex is divided into an outer and an inner region (Fig. 2C). The outer cortex is well developed, with an outer zone consisting of 3-4 layers of small polygonal and irregularly arranged, moderately thick-walled cells, the latter intermixed with tannin-containing cells. The innermost cortex zone consists of 5-6 cell layers with lignified and sclerotic cells intermixed with few raphide idioblasts in the root tip region (Fig. 2B). The inner cortex consists of 8-10 regularly arranged cell layers, the latter much larger than those in the outer cortex; a few raphide idioblasts and starch grains (Fig. 2D) were observed in this area. The endodermis is lignified in later stages of development, the $\mathrm{u}$-shaped outer walls are thin and the inner wall is slightly thickened; the pericycle is two celllayers thick (Fig. 2F). The var. simplicifrons and polyclada form above-ground adventitious roots associated to new plantlets arising from the stem. These adventitious roots that emerge 

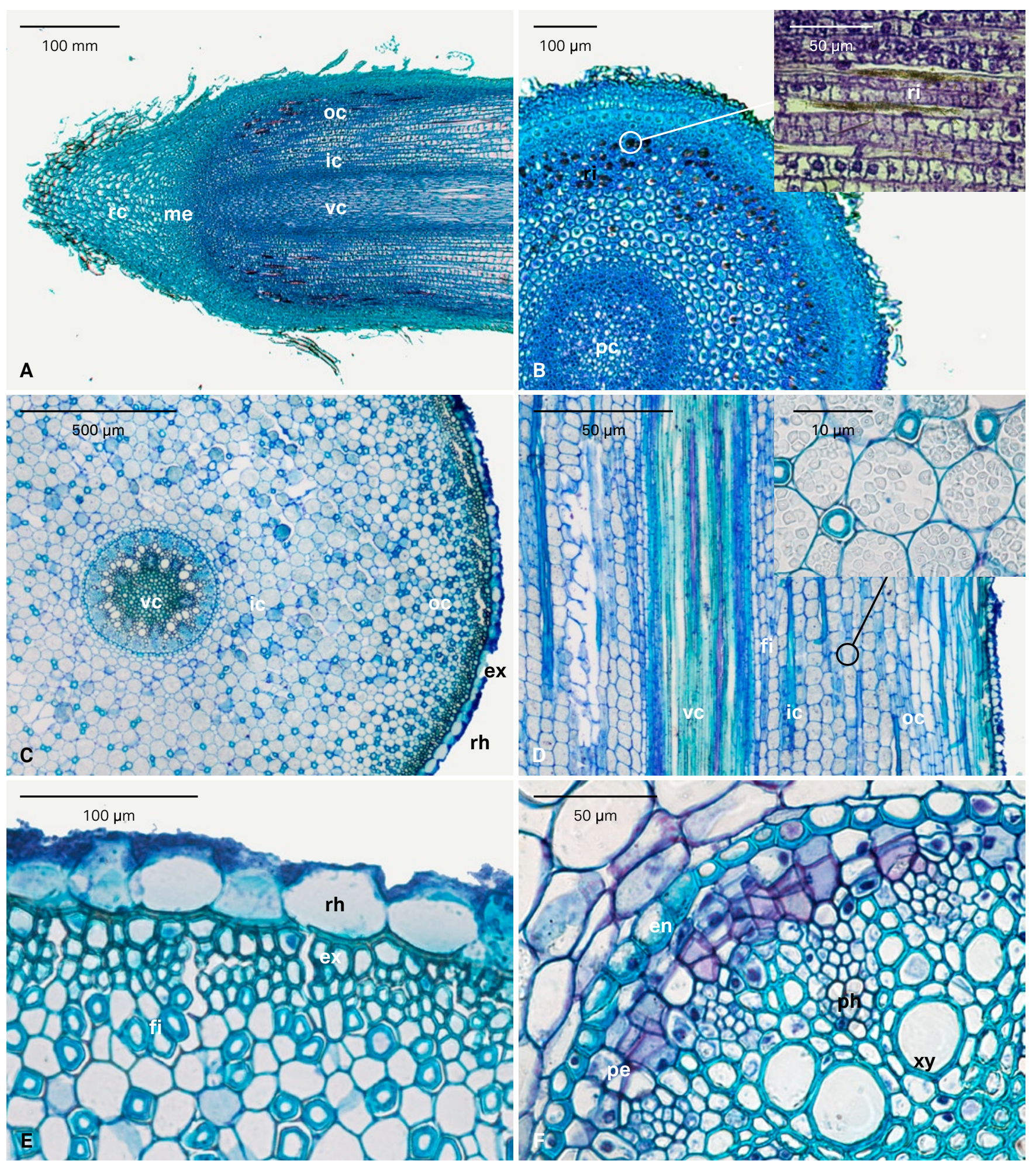

Fig. 2. - Root anatomy in Wendlandiella gracilis var. polyclada

A. Apex of the root, LS; B. Elongation area of root tip, CS; C. First order root, detail of raphide idioblasts, CS; D. First order root, detail of inner cortex starch containing cells, LS-CS.; E. Rhizodermis and exodermis, CS; F. Vascular cylinder and endodermis layer, CS.

[Abbreviations: en, endodermis; ex, exodermis; fi, fiber; ic, inner cortex; me, meristematic zone; oc, outer cortex; pc, pith vascular cylinder; pe, pericycle; ph, phloem; rc, root cap; rh, rhizoderm; ri, raphide idioblast; vc, vascular cylinder; $\mathbf{x y}, \mathbf{x y l e m ]}$ 
directly from the stems in Wendlandiella are not rare and we have also seen them on photographs of living individuals of $W$. gracilis var. polyclada (A. Bredeson s.n. NNTBG-14632) and $W$. gracilis var. simplicifrons (B. Fischer s.n. NNTBG-14633,1998).

\section{Leaves}

Each stem of Wendlandiella bears (4-)6(-11), spirally arranged leaves. Wendlandiella gracilis var. gracilis and $W$. gracilis var. polyclada have pinnate leaves (Fig. 3A [1-4]) whereas $W$. gracilis var. simplicifrons has entire and bifid leaves (Fig. 3A [5-6]). The leaf sheaths are closed, tubular, and they form an elongated crownshaft; when mature, the leaf sheaths are green and thick, becoming papery thin when dry. An ocrea is formed as a reduced and irregular apical extension of the sheath. The leaf sheaths can sometimes persist after abscission as the petiole breaks down; a ventral slit opens in a basipetal direction until the complete fall of the sheath.

The petiole is slender and circular in cross section, and the leaf rachis and blade are variable in morphology and size. Wendlandiella gracilis var. simplicifrons usually has small, entire, and bifid blades, $12-20 \mathrm{~cm}$ long, with 4-6 secondary veins. Only a few of the studied specimens had larger blades, $30-50 \mathrm{~cm}$ long, and more (7-20) secondary veins. In pinnate leaves, the rachis ranges from $2-34 \mathrm{~cm}$ long, and its length appears to be positively correlated with the number of leaflets. Generally, the width of the rachis is reduced from the base $(<$ $2 \mathrm{~mm})$ to the apex $(<1 \mathrm{~mm})$. The leaf margins are entire and lined by a conspicuous vein.

The pinnate leaves of Wendlandiella are reduplicate, with 2-6(-8) pairs of leaflets inserted on the dorsal face of the rachis in a single plane. The leaflets are lanceolate, oblanceolate, or linear and the apex is acuminate to slightly aristate; in some samples studied, there was an eccentric midrib. Differentiation between primary and secondary veins is difficult because all veins are approximately the same size. The insertion of leaflets on the leaf rachis is irregular; some samples studied had opposite pinnae (Fig. 3 [1-4]), with regular inter-leaflets distance, but having alternating segments is also common. In any case, the most apical leaflets remain strictly opposite. An interesting pattern was observed in some specimens [Balslev et al., 7650, 8060, 8064, 8069, 8078, 8088 (AAU); Schunke 1569, 2702 (F); Figueiredo et al., 880, Daly et al., 10411, Foster 8840 (MO)], in which the two most apical leaflet pairs clearly separate from the rest. Accordingly, leaf blade morphology in Wendlandiella displays all transitional stages between the entire-bifid pattern and the completely pinnate pattern (Fig. 3A [1-6]).

Leaves in Wendlandiella have dorsiventral lamina symmetry and the epidermis cells have slightly curved longitudinal walls. Stomata are concentrated on the abaxial side of the lamina (Fig. 3B-C). Hypodermis layers are lacking, and palisade mesophyll is absent. Abundant non-vascular and non-lignified fibers are present in the mesophyll especially towards the abaxial side, commonly adjacent to the epidermis. The mesophyll is composed of only $3-4$, highly chlorophyllous cell layers. The middle mesophyll cells are larger than those towards the upper and lower epidermis (Fig. 3D). A few wide and conspicuous raphide idioblasts are scattered in the mesophyll (Fig. 3D). We did not observe any special external coverings (i.e., hairs, waxes, trichomes) in vegetative organs of any of the three varieties.

\section{The inflorescence}

The inflorescences of Wendlandiella are interfoliar, once or twice branched and unisexual; all parts of the inflorescence are slender and delicate (Fig. $4 \mathrm{~A}-\mathrm{C}$ ). The visible part of the peduncle is $5-20(-40) \mathrm{cm}$ long and similar in length to the portion of the peduncle that remains hidden by the prophyll and the peduncular bract. The peduncle is elongate and dorsiventrally compressed in cross section; it bears the prophyll and a single peduncular bract. Clearly associated with peduncle features, both the inflorescence and especially the infructescence usually end up being pendulous. The prophyll is bicarinate, $1-8(-12) \mathrm{cm}$ long, shorter or rarely equal to the peduncular bract. The peduncular bract is $1-12(-18) \mathrm{cm}$ long and narrow with an acute tip. Both the prophyll and the peduncular bract persist tightly appressed to the peduncle in their proximal portions; they sometimes have long marginal slits. The prophyll and peduncular bract may be included within the leaf sheath when young, but are more often exerted and sometimes clearly exceed the peduncle at full maturity. The developing inflorescence is released by the formation of a marginal slit in the peduncular bract, and the latter is marcescent like the prophyll.

The rachis bracts are inconspicuous, short, membranous and deciduous, leaving short scars at the base of each rachilla. The rachis is $1-6(-8) \mathrm{cm}$ long and bears $5-15(-35)$, slender rachillae. Each inflorescence is branched once or twice (Fig. 4A-C). In the latter case, the rachis length reaches up to $3 \mathrm{~cm}$ and the apex of each rachilla is forked. In inflorescences of both sexes a proximal sterile portion and a distal fertile portion of the rachillae can be clearly distinguished. The fertile portion is usually much longer $(4-6 \mathrm{~cm}$ in length) than the sterile part. The rachillae are green during inflorescence development and, in the case of the female inflorescence, turn orange during fruit formation and ripening. The inflorescence rachis never exceeds $3 \mathrm{~mm}$ in width whereas the sterile and fertile rachillae are not thicker than $1.5 \mathrm{~mm}$. The female inflorescences appear to have fewer fertile axes than the male inflorescences. The male rachillae bear basal flowering units called acervuli. The female flowers are solitary (Fig. 4D) or arranged in pairs, whereas the male flowers are arranged in acervuli of two alternating rows (e.g., W. gracilis var. gracilis, 


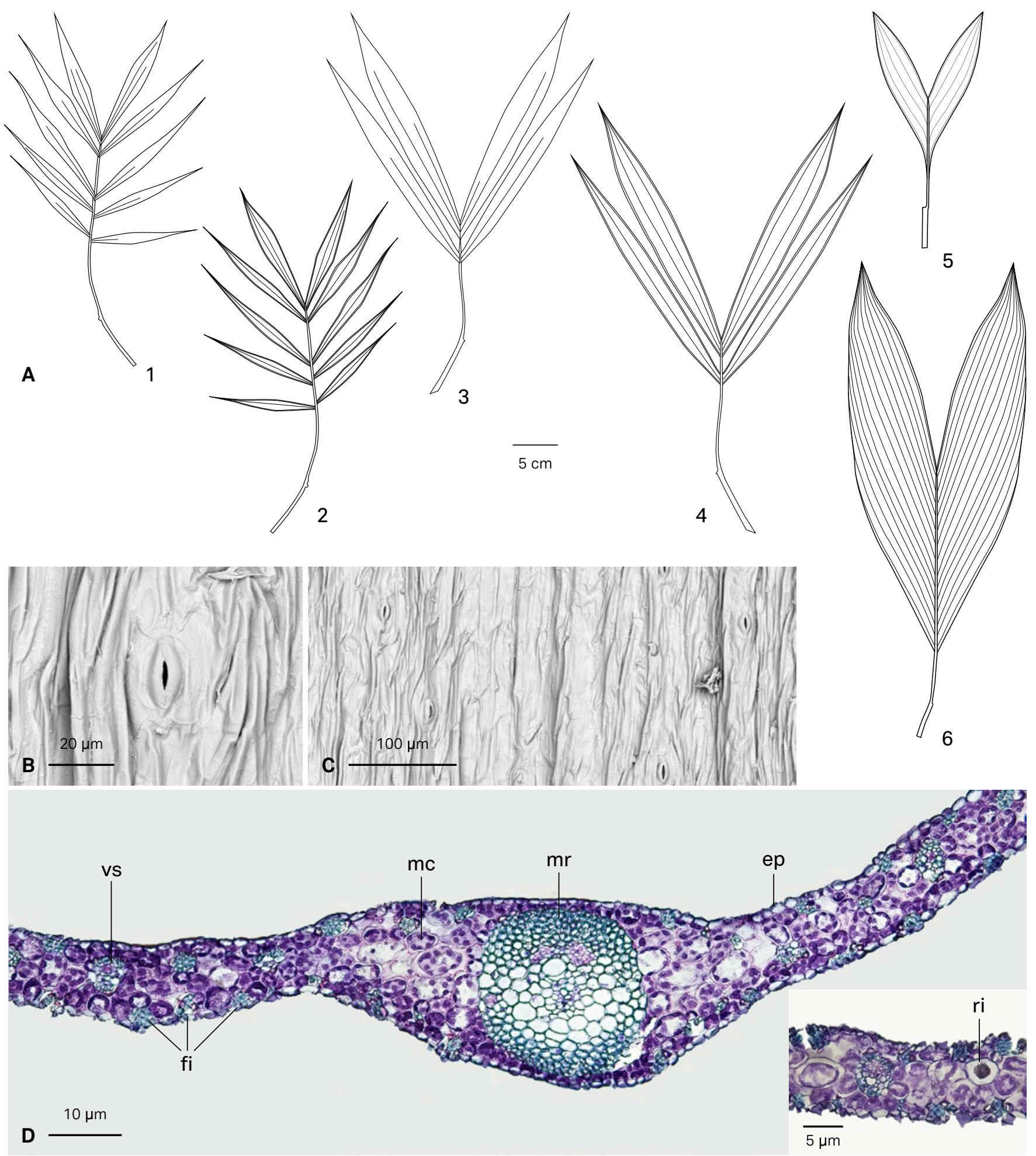

Fig. 3. - Leaf morphology and anatomy in Wendlandiella gracilis.

A. Leaf morpho-types: var. gracilis: 1. adaxial side, 2. abaxial side; var. polyclada: 3. adaxial side, 4. abaxial side; var. simplicifrons:

5. adaxial side, small-leaved morpho-type, 6. adaxial side, large-leaved morpho-type; B. Leaf blade stomata, abaxial side;

C. Leaf blade surface, abaxial side; D. Lamina anatomy (var. polyclada), CS.

[Abbreviations: ep, epidermis; fi, fiber bundles in contact with epidermal layer; mc, mesophyll cells with chloroplasts; mr, midrib;

ri, raphide idioblast; vs, vascular bundles free of surface layers] 
Fig. 4E) or arranged in an unordered flower complex. Both types of floral units are subtended by a thin, membranous and deciduous floral bract only visible at early ontogenetic stages.

\section{The flowers}

The flowers in Wendlandiella are unisexual, with an aborted sterile pistillode in male flowers and staminodes in female flowers; they are actinomorphic, small, sessile and obovoid to globose in bud (Fig. 5A-F). The calyx is composed of three valvate sepals with thin margins (Fig. 5D) which are basally fused, gibbous and distinct distally, and the lobes appressed at bud stage. The corolla is composed of three petals briefly fused at the base and becoming completely distinct and recurved at anthesis. The petals are thicker than the sepals, which are elliptic with slightly acute tips, green-yellow at anthesis.

In staminate flowers, the adaxial epidermis of the sepals has quadrangular cells with a thin cuticle, and the abaxial epidermis has dorsiventrally compressed cells. The sepals have three large vascular bundles at the base. There are large raphide idioblasts concentrated at the lobed region of the sepals in var. gracilis whereas they concentrate towards the apical regions in var. polyclada. The petals'dorsal epidermis has quadrangular cells with a thin cuticle, whereas the cells are dorsiventrally compressed in the ventral epidermis. Each petal is served by one central vascular bundle in var. polyclada whereas there are two central vascular bundles at the base of the petals in var. gracilis. Raphide idioblasts are present throughout the petals in var. gracilis but seem to be lacking in W. gracilis var. polyclada.

The androecium is composed of six distinct stamens (Fig. 5A-B) inserted in two whorls of three, surrounding a rudimentary 3-carpellate pistillode (Fig. 5C) which is basally connate and distally distinct. The three epipetalous stamens make up the inner whorl; the filaments have one small vascular bundle located towards the dorsal side; raphide idioblasts are abundant at the base of the filaments in var. polyclada, especially in the region where the filaments are fused. The anthers are dorsiventrally latrorse although there is some variation in the point of insertion of the filament on the connective. The anthers have an endothecium composed of one intermediary cell layer without apparent thickening and 1-2 raphide idioblasts intermixed in the remaining cell layers (observed in anthers of $W$. gracilis var. gracilis). The pistillode is well developed and fleshy, but lacking nectariferous tissue; it is basally syncarpous and served at the base by three vascular bundles, one at the base of each sterile carpel. Intercarpellar septa develop from the base centrifugally. Apically, the pistillode is apocarpic and several raphide idioblasts fill the mesophyll of each sterile carpel in $W$. gracilis var. gracilis but are scattered throughout the pistillode, with some concentration apically, in $W$. gracilis var. polyclada. The staminate flowers have a basipetal sequence of anthesis and become darker in coloration while developing from bud to anthesis. The pollen is ellipsoidal and slightly asymmetric, with an average length of $15 \mu \mathrm{m}$ along the grain's longest axis.

In pistillate flowers (Fig. 6A-F), the sepals have an epidermis with dorsiventrally compressed cells with thin cuticle. In $W$. gracilis var. polyclada the petals have short imbricate areas due to the overlap of short marginal projections; each sepal has three vascular bundles throughout its length (observed at the gibbous zone of the sepals); some raphide idioblasts are scattered towards the dorsal epidermis. The petals present a dorsal and ventral epidermis of dorsiventrally compressed cells with thin cuticle. In $W$. gracilis var. gracilis, each petal is served by 3-4 vascular bundles distributed towards the ventral epidermis, in particular observed at the gibbous zone of the petals. Few raphide idioblasts were observed intermixed with the vascular bundles. The gynoecium is syncarpous throughout; the three carpels are fused along their length (Fig. 6F) and topped at anthesis by three short, sessile, reflexed, and papillate stigmatic branches (Fig. 6A, B). At mid-height of the ovary the intercarpellary septa are differentiated in an acropetal and centrifugal pattern. Despite thorough anatomical observations no nectariferous tissue could be observed differentiating between neighboring carpels. The carpels postgenitally unite towards the stylar region and in this zone a pollen tube transmitting tract (PTTT) lines the ventral slit of each carpel. The stigmas have a ventral epidermis formed by quadrangular, poorly differentiated cells. Some raphide idioblasts are present in the mesophyll of the gynoecium, always concentrated towards the distal part of the gynoecium and abundant towards the stigmatic region (observed in $W$. gracilis var. polyclada). At the base of the female floral bud, we observed 9-12 vascular bundles that serve all floral whorls. At the level of the ovary, each carpel presents one dorsal bundle, 2-4 lateral bundles and 2-3 ventral bundles. Three minute staminodes, adnate to the gynoecium and each served by one small central vascular bundle, were observed in the female flower (Fig. 6C).

\section{Fruits and seeds}

The fruits of Wendlandiella are obovoid to globose, 1-seeded drupes (Fig. 7A, B) with a smooth epicarp, a thin mesocarp, and a membranous endocarp which does not attach to the seed. The fruits of $W$. gracilis are bright red when ripe (Fig. 7A, B). The fruits are relatively large $(6-8 \mathrm{~mm}) \mathrm{com}^{-}$ pared to the delicate rachillae on which they are inserted. The seed has a single ventral raphe branch curving over the top and a side branch curving around each lateral side (Fig. 7C). The endosperm is homogeneous and the embryo is laterally inserted, slightly below the middle axis of the seed. 


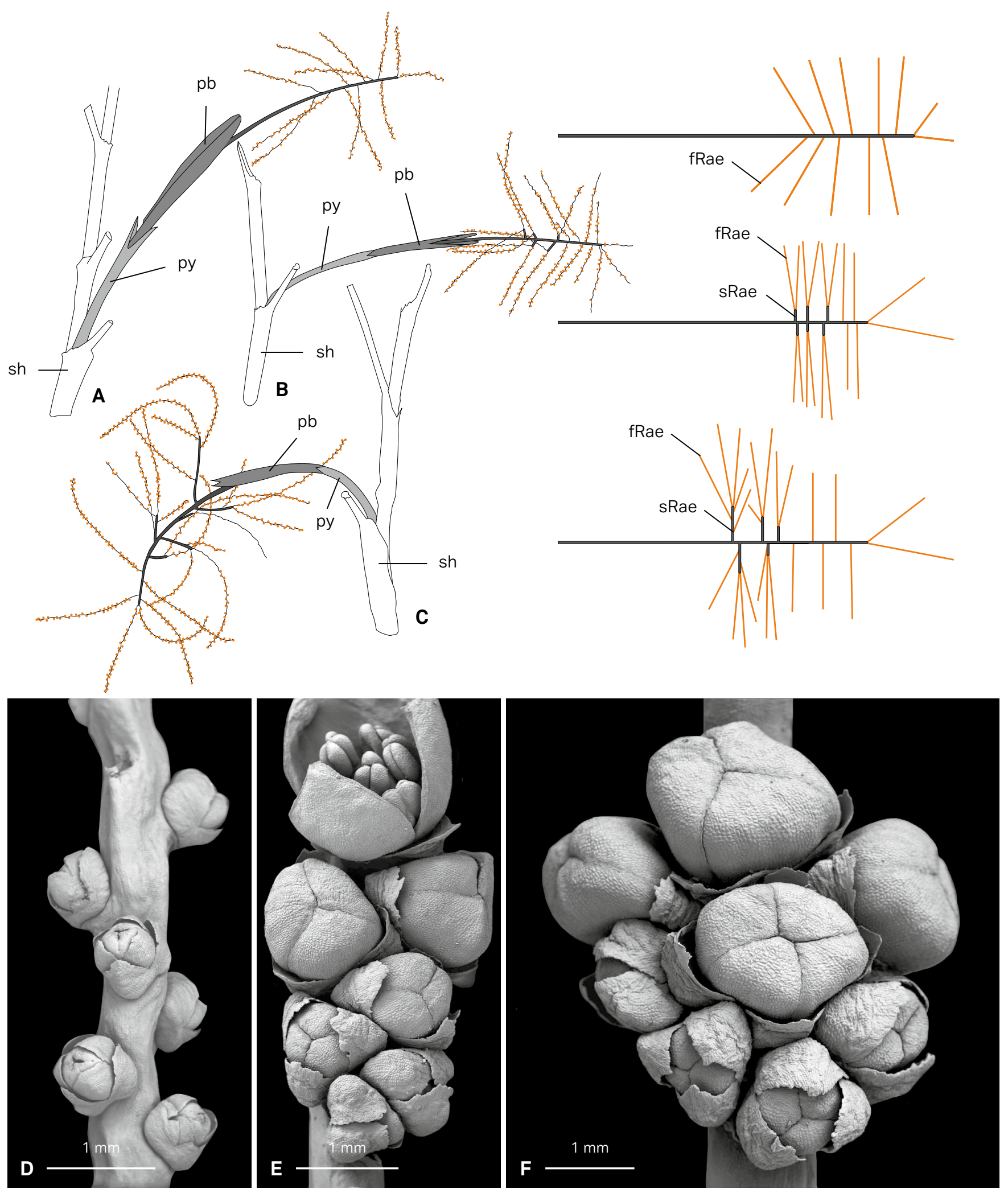

Fig. 4. - Inflorescence structure and flower arrangements in Wendlandiella gracilis.

A. 1-order ramification; B. Proximal ramification in basal rachillae; C. 2-branched order ramification in basal rachillae;

D. Solitary female flowers (var. polyclada); E. Male flowers in an acervulus of two alternating rows (var. gracilis);

F. Male flowers in an unordered acervulate complex (var. gracilis).

[Abbreviations: fRae, fertile rachillae; pb, peduncular bract; py, prophyll; sh, sheath; sRae, sterile rachillae] 


\section{Germination and seedling}

Germination is adjacent-ligular. According to M. Caixeta (pers. comm.), germination tests on $W$. gracilis var. gracilis performed in Machado de Sul (Minas Gerais, Brazil), based on seed gathered from wild populations, demonstrated that the germination of fresh seed may last from 60-210 days. In outdoor cultivation, plants flowered almost all year round and fruits developed without assistance of hand pollination. However, seeds obtained from these plants never developed and always aborted before being ripe. A. Lindstrom (pers. comm.) also did not see any seedlings in cultivated plots of Wendlandiella at Nongnooch Tropical Garden (Thailand), nor did he observe seedlings in the natural habitat of the palm. On the contrary, he observed vegetative reproduction in cultivated large clumps of this palm at Nongnooch Tropical Garden.

\section{Discussion}

\section{Main morphological features of Wendlandiella}

Here we discuss the main morphological and anatomical features of Wendlandiella in the context of its ecology and evolution within the subfamily Arecoideae. The terrestrial root system of Wendlandiella displays a relatively simple architecture resembling other small palms thriving in rain forest understory conditions, either in other members of Chamaedoreeae (e.g. Chamaedorea), as described by Seubert (1996), or as in Geonoma Willd. (Geonomateae Luerss.), a more recently diversified genus of Arecoideae (A. Briceño pers. comm.). Wendlandiella shares with most Chamaedoreeae the presence of hairy velamen, the lack of aerenchyma and the occurrence of an outer zone of the inner cortex having thin cell walls. Roots of Wendlandiella differ from other Chamaedoreeae in having a 1-layered exodermis and lacking cork and stone cells. However, additional observations are needed to confirm these apparently unique features of the genus as not all the currently recognized varieties (as defined by EYchenNe et al., 2018) were included in Seubert's root anatomical assessment or our study. The adventitious roots emerging from the basal region of the stems of Wendlandiella are relatively few in number and extremely thin, whereas those emerging from aerial rings on the stem are much more robust. In particular old stems of this palm may produce new plantlets directly from their aerial part, resembling the vegetative propagation by stem leaning and aerial layering described by Granville (1977) for the Amazonian palm Geonoma baculifera (Poit.) Kunth, which leads to a reiteration process that may strongly shape the spatial distribution of populations. Vegetative propagation along the stem also occurs in Hyospathe elegans Mart. (Skov \& BalsLev, 1989). The recent study of Edelman \& Richards (2018) included the aerial vegetative branching observed in Wendlandiella in the lateral axillary category (aerial suckering type), in which the lateral axillary branch is not limited to basal internodes.
Our research did not attempt to determine the exact origin of the aerial branching in Wendlandiella (i.e. single at each node, multiple directly from the node or a developing fascicle of branches from a single nodal branch); however, this would be an interesting subject of study given the evident facilities to access the responsible vegetative meristems in these small palms.

Our study of wild populations of Wendlandiella suggests that vegetative multiplication of these palms by developing rhizomes and plantlets directly on upper regions of the stem in the mother plant may be extremely important as a vegetative mechanism of reproduction. Wendlandiella stems still attached to their parent plants may form abundant roots, without or in direct contact with the ground. This method of vegetative propagation promotes a high success rate and may benefit from the high environmental humidity predominant in the forests where the palms thrive. Indeed, the locally dense populations often observed for Wendlandiella could be at least partially explained by prolific clonal reproduction, highly contrasting with a restricted sexual multiplication in which only a relatively low number of fruits is produced in each infructescence (Listabart h, 1992; C. Listabarth, pers. comm.). The prevailing vegetative multiplication observed in Wendlandiella represents a challenging case for evolutionary studies, in which intra- and inter-population genetic observations could reveal low genetic diversity as expected for predominantly clonal reproducing species such as reported in the early divergent monospecific palm subfamily Nypoideae (JiAn et al., 2010; Sugar et al., 2015). A better understanding of the genetic diversity is important for the development of effective conservation management programs (ELLSTRAND \& ELAM, 1993). In the case of Wendlandiella it would be particularly interesting to test current theories about whether geographically marginal populations have lower genetic diversity and higher genetic differentiation than geographically central populations.

The leaf blade morphology of Wendlandiella displays all possible transitional stages from the entire-bifid pattern found in many members of other Amazon palm genera such as Bactris Jacq. ex Scop., Geonoma Willd. and Hyospathe Mart., often associated with scant light conditions characterizing the lower strata of the forest, to the completely and regularly pinnate pattern observed in sun-exposed palms. Such large diversity has also been documented in the small Amazon palm Bactris simplicifrons Mart. (STAuffer \& BriceÑo, 2000), with which Wendlandiella grows sympatrically in some regions of the Amazon basin. Understanding the micro-ecological conditions responsible for such impressive leaf morphological diversity and its underlying genetic basis would be critical to assess the real taxonomic value currently attributed to this character in the recognition of several infraspecific taxa within a polymorphic single species. The leaf anatomy of Wendlandiella is relatively simple and fits within the patterns 

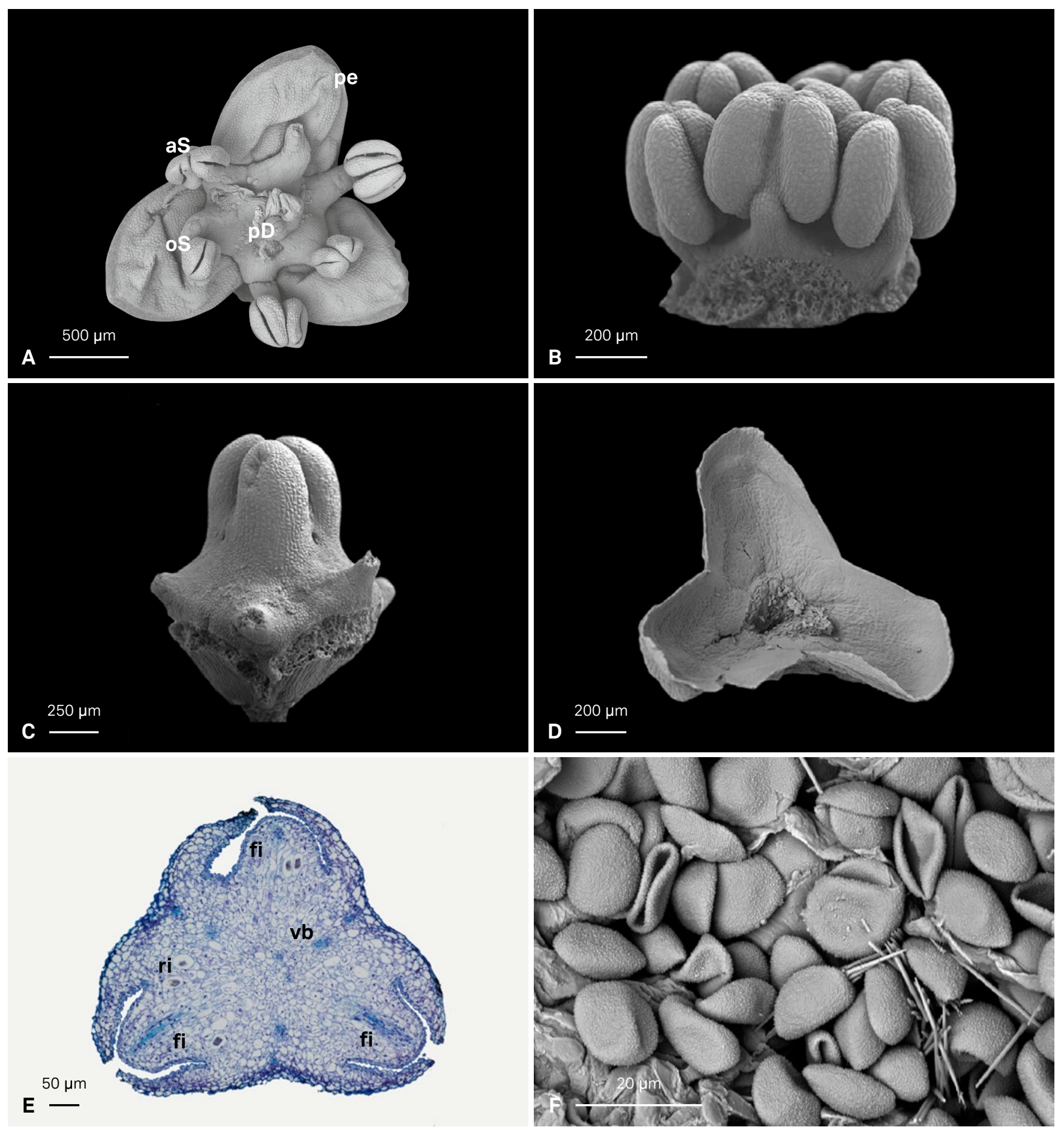

Fig. 5. - Staminate flower in Wendlandiella gracilis.

A. Anthesis (var. polyclada); B. Androecium displaying filaments and anthers (var. gracilis); C. Pistillode (var. gracilis); D. Calyx (var. gracilis); E. TS at basal level (var. polyclada); F. Pollen intermixed with raphide idioblasts (var. gracilis).

[Abbreviations: aS, alternating stamens; fi, filament; oS, opposite stamens; pD, pistillode; pe, petal; ri, raphide idioblast; vb, vascular bundle] 
already proposed by TomLinson et al. (2011), resembling in particular the genus Synechanthus H. Wendl., with which it seems to share an extremely simplified mesophyll, restricted to 3-4, highly chlorophyllous cell layers.

The peduncular bract is widely recognized as one of the most important protective structures of the palms inflorescence, in particular during its early stages of development. The apparently low protection offered by the single peduncular bract observed in Wendlandiella may be efficiently complemented by the protective leaf sheaths under which the inflorescence remains during early stages of development. Our study of Wendlandiella confirms the presence of only one peduncular bract in both male and female inflorescences, reinforcing the importance of this organ as a constant herbarium and field character that separates Wendlandiella from all other genera of Chamaedoreeae. According to Dransfield et al. (2008) multiple peduncular bracts is the most common condition in this tribe (Hyophorbe: 4-9, Synechanthus: 4-5, Gaussia: 4-7, and Chamaedorea: 2-several), and multiple peduncular bracts are also observed in all five genera of Iriarteeae which have 3-12 peduncular bracts. Our study of Wendlandiella confirms previous research (UHL \& Moore, 1978; Ortega-Chávez \& Stauffer, 2011) describing female flowers that are solitary or arranged in pairs, whereas the male flowers are arranged in either acervuli of two alternating rows or in an unordered floral complex.

\section{Structural biology and pollination ecology}

The small size of Chamaedoreeae palms that flower not more than a few meters above the ground make them easy subjects for observing pollination, but still only a few species have been studied. Wind pollination has been reported in $18 \%$ of the world's angiosperm families and it is the dominant pollination syndrome in some groups (ACKERMAN, 2000). In the palm family $7 \%$ of the studied species are wind pollinated (BARFOD et al., 2011), and animal-mediated pollination is dominant. Wind may play an important role in the reproduction of a few palm taxa (i.e. Read, 1975; Herrera, 1989), or at least act as a supporting pollination agent (ANDERson et al., 1988; SCARIOT et al.,1991; BARFoD et al., 2011; Rios et al., 2014). ListabarTH (1992) studied the reproductive biology in populations of Wendlandiella gracilis and no visiting insects were observed. Our structural studies could not detect any secretory histological features associated with the gynoecium or the pistillode, offering further support to suggest that Wendlandiella is a wind pollinated palm. The genus Chamaedorea, also often thriving in understory conditions, on the contrary, displays a wide array of pollination syndromes, ranging from primarily wind-pollinated (Otero-Arnaiz \& Oyama, 2001; Berry \& Gorchov, 2004), to insect-pollinated (Hodel, 1992; Morgan, 2007). Chamaedorea pinnatifrons (Jacq.) Oerst. has insect induced wind pollination, in which insects visiting male flowers trigger pollen release in small puffs (ListabarTh, 1992). In more derived groups of Arecoideae wind pollination has been reported in two sympatric species of Howea Becc., both of which are monoecious and endemic to Lord Howe Island (Savolainen et al., 2006). Only a few studies have addressed the role of habitat or habitat fragmentation in the wind pollination mechanisms, but it appears to be more common at higher latitudes and elevations, and in open-structured and floristically less diverse vegetation (WHITEHEAD, 1969; Culley et al., 2002). In Attalea phalerata Mart. ex Spreng. (Arecoideae, Attaleinae) in Brazil wind pollination is important when it grows in open pastures (ANDERson et al., 1988). Apart from the studies of Listabarth (1992), knowledge of wind-pollination in understory Amazon palms remains very limited. The understory conditions prevailing in rainforest may a priori be considered unsuitable for anemophily because low wind velocities caused by dense evergreen foliage, frequent rainfall and high humidity reduce pollen transport (FrIEDMAN \& BARret, 2009). However, studies in other angiosperm families (e.g. Piperaceae, Rubiaceae) show that wind pollination in understory dioecious plants can produce high fertilization rates (Merret \& Robertson, 2012). The low success of sexual reproduction in Wendlandiella may also be due to the disadvantageous interfoliar position of the inflorescences, and also its habitat in the deepest layer of the understory, where even some grasses have turned to entomophily (LISTABARTH, 1992). The compact populations of these palms, in which dense clumps grow side by side, suggests that even weak air currents controlled primarily by microclimate factors may efficiently contribute to the pollen transport in the understory of the lowland forest.

\section{Dioecy in Wendlandiella and palms in general}

Dioecy occurs in nearly half of the angiosperm families (VAmosi et al., 2003; RenNer, 2014) and dioecy is found in all palm subfamilies except the monotypic Nypoideae (Asmussen et al., 2006; Dransfield et al., 2008). Based on parsimony and maximum likelihood optimizations, NADOT et al. (2016) hypothesized that dioecy evolved directly from monoecy in Arecoideae and Calamoideae whereas it evolved from hermaphroditism in Coryphoideae. According to Castaño et al. (2014) the fact that all 107 genera of the palm subfamily Arecoideae are monoecious, with the exception of Chamaedorea and Wendlandiella, suggests strongly that the common ancestor of this group was also monoecious. Thus, the two genera could be used as an interesting model to test the different evolutionary pathways proposed by Dorken \& BARRET (2003) for the origin of dioecy in Angiosperms (gynodioecy vs monoecyparadioecy). Our study contributes to a better understanding of the reproductive structures in Chamaedoreeae, which is fundamental for further ontogenetic studies and molecular histological approaches exploring underlying sexual differentiation processes responsible for dioecy in the group. 

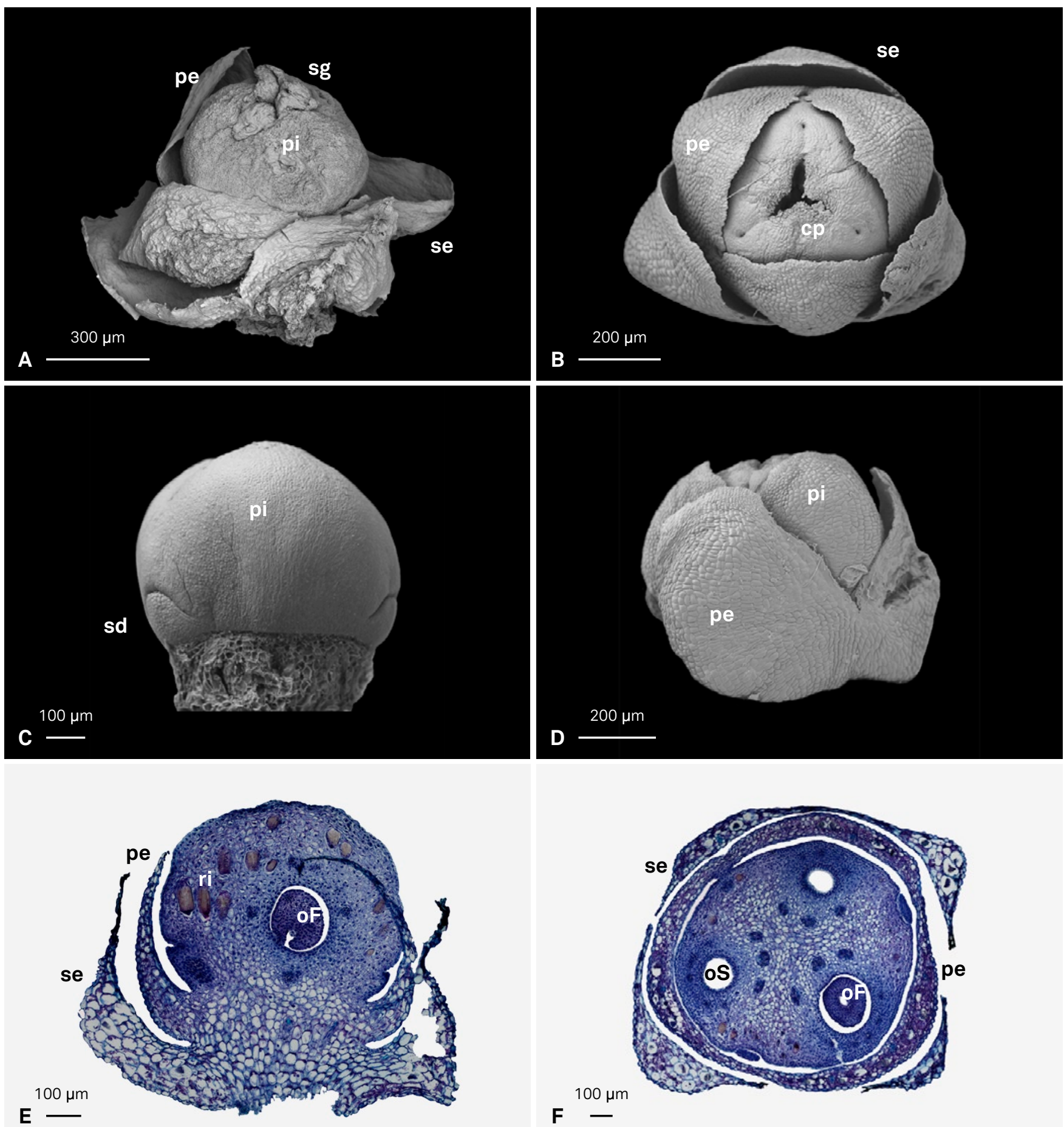

Fig. 6. - Pistillate flower of Wendlandiella gracilis.

A. Pistillate flower at anthesis (var. gracilis); B. Upper view of pistillate flower (var. polyclada); C. Gynoecium (var. polyclada);

D. Corolla and gynoecium (var. polyclada); E. Flower bud, LS (var. polyclada); F. Flower bud, TS (var. polyclada).

[Abbreviations: $\mathbf{c p}$, carpel; oF, fertile ovary; oS, sterile ovary; pe, petal; pi, pistil; ri, raphide idioblast; sd, staminode; se, sepal; sg, stigmatic branch] 

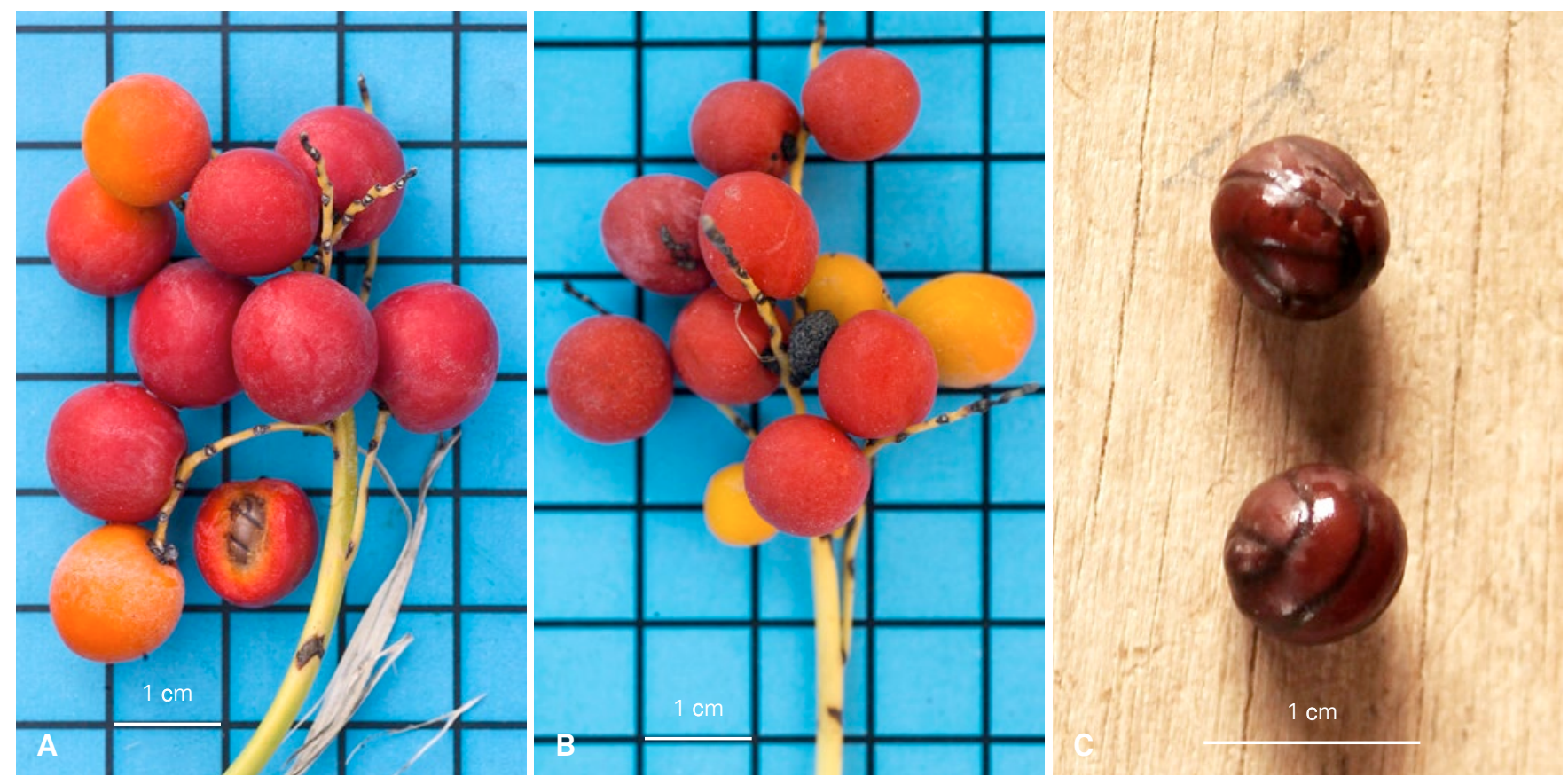

Fig. 7. - Fruits and seeds of Wendlandiella gracilis.

A. Ripe fruit (var. gracilis); B. Ripe fruit (var. simplicifrons); C. Seed (var. gracilis).

[Plant cultivated by H. Lorenzi in the Instituto Plantarum Botanical Garden, Campinas, Brazil] [Photos: A-B: H. Lorenzi; C: M. Caixeta]

\section{Acknowledgements}

The present study was undertaken by the second author (JE) at the AgroParisTech - University of Montpellier (France) and the CJBG. Financial support to JE was generously provided by the city of Geneva (research internship). HB was supported through the project Palm Harvest Impacts in Tropical Forest - PALMS (FP7-ENB-2007-1; EU Grant Agreement 212631) and the Danish Council for Independent Research - Natural Sciences (grant \#4181-00158 to HB). Throughout this work we were also supported by the staff of the herbarium and the library of the CJBG. We thank Dr. James Tregear and Myriam Collin (DIADE Research Unit at IRD - Montpellier, France) for making available fresh material of $W$. gracilis var. polyclada. High-resolution pictures and observations were shared by Cesar Grandes (curator of the AMAZ - Iquitos Herbarium), Donald R. Hodel (University of California), and Dr. Anders J. Lindstrom (Nongnooch Tropical Garden,
Thailand). We appreciate the support of Dr. N. Tkach and Dr. M. Röser (University of Halle Wittemberg) for providing samples of $W$. gracilis var. gracilis. We are indebted to the Instituto Plantarum and its director Dr. Harri Lorenzi, together with the Brazilian plant collector Mauricio Moureira Caixeta for images of cultivated Wendlandiella. Scanning Electronic Microscopy was possible through the collaboration with Dr. André Piuz (Natural History Museum of Geneva). We are particularly indebted to the curators of the herbaria AAU, B, BH, CEN, F, FTG, G, HAL, INPA, LPB, MO, NY, and WU for loans of herbarium material. We dedicate this paper to our colleagues Jean-Christophe Pintaud (1970-2015) and Gloria Galeano (1958-2016), worldwide renowned palm experts and great lovers of Amazonian palms. 


\section{References}

AAU [Aarhus University] (2019). AAU Herbarium Database. [http://www.aubot.dk/search_form.php]

Ackerman, J.D. (2000). Abiotic pollen and pollination: ecological, functional, and evolutionary perspectives. Pl. Syst. Evol. 222: 167-185.

Anderson, A.B., W.L. Overal \& A. Henderson (1988). Pollination ecology of a forest dominant palm (Orbygnia phalerata Mart.) in northern Brazil. Biotropica 20: 192-205.

Asmussen, C.B., J. Dransfield, V. Deickmann, A.S. Barfod, J.C. Pintaud \& W.J. Baker (2006). A new subfamily classification of the palm family (Arecaceae): evidence from plastid DNA phylogeny. Bot. J. Linn. Soc. 151: 15-38.

Baker, W.J., M.V. Norup, J.J. Clar kson, T.L.P. Couvreur, J.L. Dowe, C.E. Lewis, J.C. Pintaud, V. Savolainen, T. Wilmot \&M.W. Chase (2011). Phylogenetic relationships among arecoid palms (Arecaceae: Arecoideae). Ann. Bot. (Oxford) 108: 1417-1432.

Barfod, A.S., M. Hagen \& F. Borchsenius (2011). Twenty-five years of progress in understanding pollination mechanisms in palms (Arecaceae). Ann. Bot. (Oxford) 108: 1503-1516.

Berry, E.J. \& D.I. Gorchov (2004). Reproductive biology of the dioecious understory palm Chamaedorea radicalis in a Mexican cloud forest. Pollination vector, flowering phenology and female fecundity. J. Trop. Ecol. 20: 369-376.

CANO, A. (2018). What can palm evolution in time and space say about the historical assembly of diversity in the Caribbean and Central America? PhD Thesis, University of Geneva \& CJBG.

Castaño, F., F.W. Stauffer, X. Marquinez, M. Crèvecoeur, M. Collin, J.C. Pintaud \& J. Tregear (2014). Floral structure and development in the monoecious palm Gaussia attenuata (Arecaceae; Arecoideae). Ann. Bot. (Oxford) 114: 1483-1495.

Comer, J.R., W.B. Zomlefer, C.F. Barrett, J.I. Davis, D.W. Stevenson, K. Heyduk \& J.H. Leebens-Mack (2015). Resolving relationships within the palm subfamily Arecoideae (Arecaceae) using plastid sequences derived from next-generation sequencing. Amer. J. Bot. 102: 888-899.

Cuenca, A., C.B. Asmussen-Lange \& F. Borchsenius (2008). A dated phylogeny of the palm tribe Chamaedoreeae supports Eocene dispersal between Africa, North and South America. Molec. Phylogen. Evol. 46: 760-775.

Cuenca, A., J. Dransfield \& C.B. Asmussen-Lange (2009). Phylogeny and evolution of morphological characters in tribe Chamaedoreeae (Arecaceae). Taxon 58: 1092-1110.

Culley, T., S. Weller \& A. Sakai (2002). The evolution of wind pollination in angiosperms. Trends Ecol. Evol. 17: 361-369.

Granville, J.J. DE (1977). Notes biologiques sur quelques palmiers guyanais. Cah. ORSTOM, Sér. Biol. 12: 347-353.
Dorken, M.M.E. \& S.C. Barrett (2003). Life-history differentiation and the maintenance of monoecy and dioecy in Sagittaria latifolia (Alismataceae). Evolution 57: 1973-1988.

Dransfield, J., N.W. Uhl, C.B. Asmussen, W.J. Baker, M.M. Harley \& C.E. Lewis (2008). Genera Palmarum: the evolution and classification of palms. Kew Publishing.

Edelman, S. \& J. Richards (in press). Review of vegetative branching in the Palms (Arecaceae). Bot. Rev. (Lancaster). DOI: https:// doi.org/10.1007/s12229-018-9200-2

Ellstrand, N.C. \& D.R. Elam (1993). Population genetic consequences of small population size: implications for plant conservation. Annual Rev. Ecol. Syst. 24: 217-242.

Eychenne, J., N. Ortega, H. Balslev, R. Muscarella \& F.W. STAuffer (2018). Taxonomic revision, distribution and ecology of Wendlandiella (Arecaceae: Arecoideae: Chamaedoreeae). Webbia 73: 179-190.

Friedman, J. \& S.C. Barrett (2009). Wind of change: new insights on the ecology and evolution of pollination and mating in windpollinated plants. Ann. Bot. (Oxford) 103: 1515-1527.

Henderson, A. (1986). A review of pollination studies in the Palmae. Bot. Rev. (Lancaster) 52: 221-259.

Henderson, A. (1995). The palms of the Amazon. Oxford University Press.

Henderson, A., G. Galeano \& R. Bernal (1995). A field guide to the palms of the Americas. The New York Botanical Garden Press.

Herrera, J. (1989). On the reproductive biology of the dwarf palm, Chamaerops humilis in Southern Spain. Principes 33: 27-32.

Hodel, D.R. (1992). Chamaedorea palms: the species and their cultivation. International Palm Society.

Igersheim, A. \& O. Cichocki (1996). A simple method for microtome sectioning of prehistoric charcoal specimens, embedded in 2-hidroxyethyl methacrylate (HEMA). Rev. Palaeobot. Palynol. 92: 389-393.

JiAn, S., B. JiAwei, R. HAi \& Y. HAifei (2010). Low genetic variation detected within the widespread mangrove species Nypa fruticans (Palmae) from Southeast Asia. Aquatic Bot. 92: 23-27.

Listabarth, C. (1992). Insect-induced wind pollination of the palm Chamaedorea pinnatifrons and pollination in the related Wendlandiella sp. Biodivers. E Conservation 1: 39-50.

Merrett, M.F. \& A.W. Robertson (2012). The efficacy of wind pollination in a small understory shrub (Coprosma spathulata) in native forest of the Waikato region, New Zealand. New Zealand J. Bot. 50: 37-49.

Moore, H.E. (1975). The major groups of palms and their distribution. Quart. Rev. Biol. 50: 94-144. 
Morgan, H.P. (2007). Thrips as primary pollinators of sympatric species of Chamaedorea (Arecaceae) in Belize. PhD Thesis, University of New York.

Nadot, S., E. Alapetite, W.J. Baker, J.W.Tregear \& A. Barfod (2016). The palm family (Arecaceae): a microcosm of sexual system evolution. Bot. J. Linn. Soc. 182: 376-388.

Ortega, N. (2010). Contribution to the morphologic and systematic study of the palm tribe Chamaedoreeae Drude (Arecaceae, Arecoideae). Master Thesis, University of Geneva \& CJBG.

Ortega-Chávez, N. \& F.W. Stauffer (2011). Ontogeny and structure of the acervulate partial inflorescence in Hyophorbe lagenicaulis (Arecaceae; Arecoideae). Ann. Bot. (Oxford) 108: 1517-1527.

Otero-Arnaiz, A. \& K. Oyama (2001). Reproductive phenology seed-set and pollination in Chamaedorea alternans, an understorey dioecious palm in a rain forest in Mexico.J. Trop. Ecol. 17: 745-754.

Preibisch, S., S. Saalfeld \& P. Tomancak (2009). Globally optimal stitching of tiled 3D microscopic image acquisitions. Bioinformatics 25: 1463-1465.

Read, R. (1975). The genus Thrinax. Palmae: Coryphoideae. Smithsonian Contr. Bot. 19.

Renner, S.S. (2014). The relative and absolute frequencies of angiosperm sexual systems: dioecy, monoecy, gynoedioecy, and an update online database. Amer. J. Bot. 101: 1588-1596.

Rios, L., E.J. Fuchs, D.R. Hodel \& A. Cascante-Marín (2014). Neither insects nor wind: ambophily in dioecious Chamaedorea palms (Arecaceae). Pl. Biol. (Stuttgart) 16: 702-710.

Savolainen, V., M.C. Anstett, C. Lexer, I. Hutton, J.J. Clarkson, M.V. Norup, M.P. Powell, D. Springate, N. Salamin \& W.J. Baker (2006). Sympatric speciation in palms on an oceanic island. Nature 441: 210-213.

Scariot, A.O., E. Lleras \& J.D. Hay (1991). Reproductive biology of the palm Acrocomia aculeata in Central Brazil. Biotropica 23: $12-22$.

Seubert, E. (1996). Root anatomy of palms III. Ceroxyloideae, Nypoideae, Phytelephantoideae. Feddes Repert. 107: 597-619.

Skov, F. \& H. Balslev (1989). A revision of Hyospathe (Arecaceae). Nordic J. Bot. 9: 189-202.

Stauffer, F.W. \& A. Briceño (2000). Estudio preliminar de la variación morfológica de Bactris simplicifrons Mart. (Arecaceae) en Venezuela. Sci. Guaianae 10: 121-126.

Sugai, K., S. Watanabe, T. Kuishi, S. Imura, K. Ishigaki, M. Үокота \& S. Yanagawa (2015). Extremely low genetic diversity of the northern limit populations of Nypa fruticans (Arecaceae) on Iriomote Island, Japan. Conservation Genet. 17: 221-228.

Thomas, M.M., N.C. Garwood, W.J. Baker, S.A. Henderson, S.J. Russell, D.R. Hodel \& R.M. Bateman (2006). Molecular phylogeny of the palm genus Chamaedorea, based on the lowcopy nuclear genes PRK and RPB2. Molec. Phylogen. Evol. 38: 398-415.

Tomlinson, P.B., J.W. Horn \& J.B. Fisher (2011). The anatomy of palms, Arecaceae-Palmae. Oxford University Press.

Uhl, N.W. \& J. Dransfield (1987). Genera Palmarum: a classification of palms based on the work of Harold E. Moore, Jr. / Natalie W. Uhl and John Dransfield. International Palm Society.

UhL, N.W. \& H.E. Moore (1978). The structure of the acervulus, the flower cluster of Chamaedoreoid palms. Amer. J. Bot. 65: 197-204.

Vamosi, J.C., S.P. Otтo \& S.C.H. Barrett (2003). Phylogenetic analysis of the ecological correlates of dioecy in angiosperms. $J$. Evol. Biol. 16: 1006-1018.

Whitehead, D.R. (1969). Wind pollination in the angiosperms: evolutionary and environmental considerations. Evolution 23: 28-35. 